\title{
Effects of perceptions of corporate social performance on individual purchasing behaviour in South African university students: A mixed-method approach
}

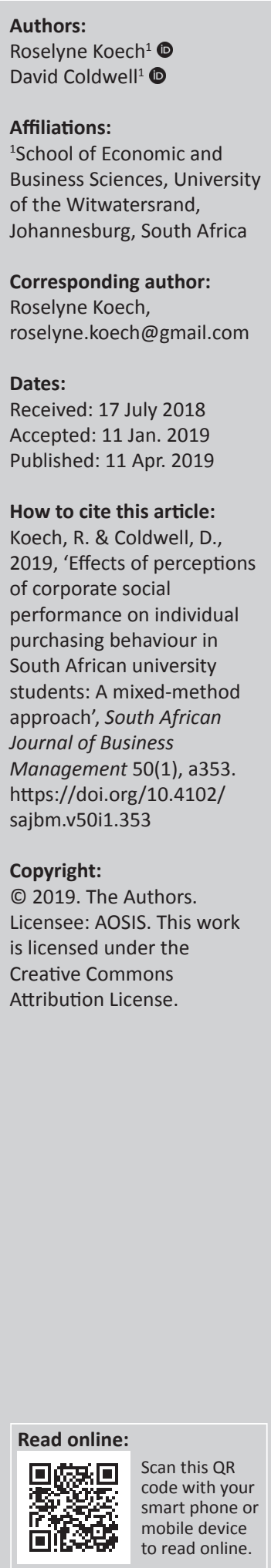

Background: Corporate social performance (CSP) has been widely researched in the past. However, few empirical studies, especially in the African context, have been conducted. In particular, a highly under-researched topic is the role that corporate social responsibility (CSR) plays in an individual's actual purchasing behaviour.

Objectives: This article examines whether the perception of CSR plays a role in purchasing decisions of South African university students. It adopts Carroll's CSR definition that comprises economic, legal, ethical and philanthropic responsibilities.

Methods: A mixed-method technique was used to analyse the data obtained from a sample survey $(n=145)$ and in-depth interviews $(n=30)$ of South African university students. An exploratory factor analysis was performed which revealed that legal, ethical and philanthropic factors influence individual purchasing behaviour.

Results: The findings show that companies that fulfil consumer expectations of social responsibility tend to generate positive perceptions of CSP, which lead to actual purchases of goods and services from the company concerned. The findings also show that CSR plays a relatively minor role in individuals' actual purchasing behaviour, and the other-than-CSP aspects influencing the outcome are explained.

Conclusion: The study extends the theoretical understanding of CSR and its role in purchasing decisions of individuals in the African context.

Keywords: Corporate social responsibility; corporate social performance; perceptions; purchasing behaviour; South African university students.

\section{Introduction}

The concept of corporate social responsibility (CSR) continues to receive significant attention in both the academic and corporate fields as evidenced by growing scholarly research on the topic. Corporate social responsibility recognises the close relationship between a business and society, and as such these relationships must be foregrounded and deftly managed as corporations and stakeholders pursue their respective goals (Crane, McWilliams, Matten, Moon, \& Siegel, 2008, p. 27). In essence, CSR shapes the way business and society relate to each other. Human social behaviour in society requires a degree of give and take to survive in today's ever-competitive environment. Society expects that by supporting business organisations through buying their goods and services; business organisations, on their part, reciprocate by going beyond their profitmaking agenda to help solve social and environmental issues. 'Traditional views about competitiveness, survival and profitability are being swept away' (Crane et al., 2008, p. 33). Instead, CSR emphasises co-dependency, or as Peters (2009, p. 6) puts it, 'successful companies need an intact society, just as an intact society needs successful companies, and this recognition forms the basis for responsible corporate action'.

Today, consumer awareness and interest in CSR initiatives of companies are increasing (Berens, Riel, \& Bruggen, 2005; Boonpattarakan, 2012). Consumers are one of the most influential stakeholder groups and seem to be notably responsible for a company's CSR activities (Bhattacharya \& Sen, 2004). For instance, a survey by a market research and information firm (Kantar TNS) evaluating the influence of CSR strategies on consumer behaviour showed that, in 2014, 42\% of consumers acknowledged that CSR had a high impact on their purchasing behaviour - a proportion that grew to 53\% in 2017 (Wall, 2017). Similarly, another study by the Cone Communications / Ebiquity Global CSR (2015) revealed that $81 \%$ of consumers 
stated that they would personally take the initiative to resolve social and environmental issues.

In South Africa, political change and the need to address the unequal distribution of wealth have bolstered CSR's relevance in society and related research at large. It is mainly seen as a tangible effort by companies to redress their historical contributions to, or benefits from, the apartheid system (Juggernath, Rampersad, \& Reddy, 2011). This has seen many companies in South Africa, in line with companies globally, acknowledge that not only is CSR the 'right thing to do', it can also result in efficiency gains and manifest itself as a win-win strategy (Flores-Araoz, 2011; Rangan, Chase, \& Karim, 2012). Today, largely through the private sector's growing function in socio-economic reconstruction and development, and implementation of local legislation (e.g. Broad-Based Black Economic Empowerment [BBBEE] Act (Act No. 53 of 2003), government and businesses in South Africa have come together to partner in pushing a social responsibility agenda (Skinner \& Mersham, 2008). Consequently, there has been a significant growth in CSR participation, with many leading companies and brands showing commitment to CSR. As a result, these companies have witnessed a significant benefit in economic, social and environmental capital (HR Pulse, 2016). However, mandatory legislation and regulations applied in the South African context do not necessarily guarantee any significant value to the stakeholders (Verhoeven, Murthy, \& Soares de Oliveira, 2014).

Despite this rapidly increasing body of academic research and publication over the last 5 years, most of the research has focused on western countries (Fatma, Rahman, \& Khan, 2015). Studies investigating the impact of CSP on individual actual purchasing behaviour in developing countries are relatively scarce. Particularly, mixed-method literature on the impact of corporate social performance (CSP) on individual perceptions and consumer behaviour in South Africa is scarce. Therefore, further research in this area is called for because of the currently significant rise in awareness and practice of CSR in emerging economies from intensifying concerns about 'lack of good governance and irresponsible business practices' (Azmat, 2015, p. 167). More importantly, mainstream considerations of CSR assume a universal set of conditions, which are not necessarily the same in developing countries (Newell, 2005); as Idemudia (2011) commented, the circumstances in emerging economies shape the nature of obligations to which businesses should attend in various ways. These reasons, coupled with the effects of globalisation and existing stringent competitive environments emerging with the increase in power of multinational corporations, have put businesses in developing countries under tremendous pressure to fulfil their social responsibility (Azmat, 2015).

This article aims to address the above-mentioned gap in the extant literature by examining the effects of perceptions of CSP on the purchasing behaviour of South African university students. Specifically, the article focuses on the African context, and in particular, South Africa, to bring an understanding of whether engaging in CSR at the grassroots level impacts the way individuals in this context perceive companies and whether such perceptions translate into actual purchases of goods and services.

The study adopts Carroll's (1991, p. 41) pyramidal model of CSR, which includes 'economic, legal, ethical and philanthropic responsibilities', for empirical analysis. The framework was chosen because of its widespread usage in research (Carroll, 2016; Visser, 2006) and is the most influential (Baden, 2016) CSR model available. However, there has been increasing research questioning the relative importance of Carroll's rankings of CSR constructs in non-western countries (Baden, 2016; Carroll, 2016; Visser, 2006). For instance, recent studies (e.g. Eshra \& Beshir, 2017; Nochai \& Nochai, 2014) on CSR and consumer buying behaviour produced equivocal empirical results regarding the original model. This article examines the effects of perceptions of CSP on South African university students. Insights into this group of consumers are useful in understanding consumer reactions to CSR from a South African perspective - a country uniquely labelled as the 'rainbow nation' after the apartheid era because of its culturally diverse society and the recognition of South African market globally. Since sustainable development concerns of the 21st century have grown in importance and urgency, answers to questions about producer and consumer behaviour have become increasingly more relevant and important. This article, therefore, addresses the following research questions:

- Does CSP influence the individual purchasing behaviour of university students in South Africa?

- Which dimensions of Carroll's pyramid of CSR model (1991) have a significant effect on South African university students' purchasing behaviour, and to what extent?

- What are the other-than-CSP factors that influence South African university students' purchasing behaviour?

The study makes several contributions. Firstly, it contributes to the emergent body of literature and research on CSR theory and practice in the African context in general and exposes the effects of CSP on the individual purchasing behaviour of South African university students, in particular. More importantly, it challenges the applicability of Carroll's CSR model in an African context. In this way, the article contributes to an important area of research, given the rising practice of CSR by companies in South Africa and the increasing awareness of its significance in society. Secondly, it replicates the findings of previous studies on CSR and buying behaviour (Bhattacharya \& Sen, 2001, 2004; Brown \& Dacin, 1997; Sen \& Bhattacharya, 2004; Butt, 2016), which show that positive perception of CSR has a direct impact on buying behaviour. Thirdly, it concurs with other studies that show that CSR only plays a minor role in consumption decisions (Mohr, Webb \& Harris, 2001) and that there are numerous other factors shown to influence individual buying behaviour (Marquina, 2010; Mohr et al. 2001; Sen \& Bhattacharya, 2001). Fourthly, insight into an individual's attitude towards CSP is crucial for the intelligent development of organisational CSP policy that is able to have a positive influence on societal well-being, 
as well as the overall performance of a company. The study aims to be of value not only to academics focusing on CSR, but also to business leaders, managers and investors who want to understand consumers' expectations of CSR and how it affects their companies' business effectiveness.

The article is structured as follows: After the Introduction, the 'Literature review' section reviews relevant literature. The 'Research method' section describes the research design and data used in the article; the 'Results' section presents the results of the study, while the 'Conclusion' section provides a conclusion of the article.

\section{Literature review}

\section{The concept of corporate social responsibility and corporate social performance}

As a result of its recent growth and popularity, many CSR conceptualisations exist. Piedade and Thomas (2006, p. 58) pointed out that 'most scholars agree that there is no universally accepted definition of CSR or a definitive framework of how it should be applied'. The current research adopts a popular and widely accepted definition of CSR, that is, Carroll's definition, which states that 'the social responsibility of business encompasses the economic, legal, ethical, and discretionary expectations that society has of organisations at a given point in time' (Carroll, 1979, p. 500). CSP 'is used as an indicator for measuring the performance of CSR and the success or failure of related programmes, policies and strategies' (Suciu, Gherheş, \& Petcu, 2010, p. 847). Scholars such as Suciu et al. (2010) highlight that it is just as important to scrutinise a company's performance in other fields (e.g. the social or environmental), despite the fact that these are less measurable than traditional financial indicators.

There are different approaches available to assess CSR performance. For instance, Wood (1991, p. 694) devised a CSP model that 'composed of principles of CSR, processes of corporate social responsiveness and outcomes of corporate behaviour'. Carroll (2000) pointed out that CSP should be seen as a comprehensive assessment of a firm's overall social performance. The advantage of the CSP concept over previous concepts is its 'development of ideas of social responsibility, integrated responsibility, and responsiveness, which allow for a more pragmatic orientation' (Ghobadian, Money, \& Hillenbrand, 2015, p. 275).

\section{Carroll's four dimensions of corporate social responsibility}

In a seminal article, Carroll (1979, p. 499) exhibited CSR as a concept that 'encompasses the economic, legal, ethical, and discretionary categories of business'. Carroll (1991, p. 41) later refined his meaning of CSR into a four-section 'pyramid' including 'economic, legal, ethical and philanthropic responsibilities'. Establishing the base of the pyramid, the foundation upon which all others rest, is economic responsibility. Carroll clarified that the economic responsibility of a business is 'to produce goods and services that society desires and to sell them at a profit' (Carroll, 1979, p. 500). From this viewpoint, business is the basic economic unit of society and all its other roles are founded on this fundamental principle. The second level of the pyramid is legal responsibility, which states that corporations will abide by, and operate according to, the relevant 'laws and regulations as partial fulfilment of the social contract between business and society' (Carroll, 1979, p. 500). Society anticipates that a business will satisfy its economic mission within the framework of legal requirements, put forward by the societal lawful framework and as indicated by the 'codified ethics' of the society (Carroll, 1979, 1991). The third level of the pyramid is ethical responsibility. Carroll (1979) considers these as additional behaviours and activities that are not necessarily codified into law but are nevertheless expected of businesses by society. Such responsibilities are mainly rooted in 'religious convictions, humane principles, and human rights commitments, and include respecting people, avoiding social harm, and preventing social injury' (Jamali \& Mirshak, 2007, p. 246). The apex of the pyramid is discretionary responsibility in the original formulation. Here, firms can exercise their own discretion in deciding on specific philanthropic commitments intended to give back to society (Carroll, 1979). Examples of such activities include 'conducting in-house training programmes for drug abusers, training the unemployed, or providing day-care centres for working mothers' (Carroll, 1979, p. 500).

\section{Effects of perceptions of corporate social performance on individual purchasing behaviour}

The concept of CSR has increasingly received consideration from managers and researchers, especially in the areas of consumer perception and response of CSR (Arli \& Lasmono, 2010). Bhattacharya and Sen (2004) demonstrated that among all the stakeholders of a company, purchasers are most impacted by the social activities attempted by a firm. Some of the main findings presented in the CSR literature have shown that consumers are interested in the social behaviour of firms, and this behaviour positively influences their purchasing decisions (e.g. Butt, 2016; Castaldo, Perrini, Misani, \& Tencati, 2009; Öberseder, Schlegelmilch, \& Gruber, 2011; Smith \& Langford, 2009). This is evident in the studies performed by Sen and Bhattacharya (2001) and Brown and Dacin (1997), which showed that perceived CSR has a direct impact on individual purchasing intentions. Other studies, including Romani, Grappi and Bagozzi (2016), found there was a positive relationship between consumer behavioural responses towards companies that engage in CSR initiatives and their support for other green products, while Pino, Amatulli, De Angelis and Peluso (2016) demonstrated that producers' fulfilment of philanthropic and legal responsibilities positively affected Italian purchasers' attitudes towards genetically modified foods and their intentions to buy such products.

In South Africa, an increasing number of companies are adopting some form of CSR. This is attributed to 'augmented stakeholder demands for companies to take responsibility for their actions' (Scherer \& Palazzo, 2011, p. 907), and through 
government efforts, such as the Broad Black Economic Empowerment (BBEE) codes, to combat social imbalances created by the apartheid era (Flores-Araoz, 2011). Although literature on individual consumer behaviour response to CSR in South Africa is scarce, available research shows that companies' CSR initiatives have an impact on consumer behaviour. For instance, Van Heerden and De Beer (2016, p. 161) conducted a survey at the National Zoological Gardens of South Africa to determine whether a relationship between consumer attitudes towards Coca Cola's CSR activities and their propensity to purchase Coca Cola products existed. The study found that consumers who perceived Coca Cola as being socially responsible were likely to report positive consumer behaviour towards Coca Cola products. In addition, Coldwell and Joosub (2014) observed that accounting students' perceptions of prominent CSR companies in South Africa were associated with higher tendencies to purchase goods and/or shares from those companies.

A considerable body of research demonstrates that the relationship between a corporation's CSR activities and consumers' response is not always direct and immediately apparent (e.g. Butt, 2016; Fatma et al., 2015; Marquina, 2010). Research shows that the relationship is complex and is influenced by numerous factors 'operating at the individual level (e.g., consumer personal preferences, perceptions and values) and at the company level (company's domain of corporate social performance)' (Bhattacharya \& Sen, 2004, p. 10; Butt, 2016, p. 214). Furthermore, studies have shown that in spite of customers' enthusiasm for CSR and its perceived effect on buying behaviour, in reality, 'CSR still only plays a minor role in consumption decisions' (Mohr et al., 2001, p. 60). Numerous other factors are shown to influence buying behaviour, which includes trade-offs with traditional criteria like price, quality, convenience and lack of information (Marquina, 2010; Mohr et al. 2001; Sen and Bhattacharya, 2001).

\section{Research method \\ Research approach}

A mixed-method (MM) research design that combines both survey and interviews was used to collect data on the effects of perceptions of CSP on the individual purchasing behaviour of South African university students. The underlying reason for using this approach, as argued by Coldwell (2007, p. 2), was that the perception of causality when associated with the social sciences generates various additional challenges because 'human social behaviour unlike the behaviour of natural physical phenomena is not governed by invariable laws'. As evident in this study, although the quantitative technique was used to address the quantifiable measures of CSP through measurements of variables, its 'objectivity' was not able to capture the social reality of the university students' experiences in South Africa. The social nature of the study dictated for qualitative methodologies to be incorporated into the research design in an effort to better understand the personal experiences of the university students. An explanatory sequential design was employed, where the questionnaire survey was administered first, followed by interviews aimed at gaining in-depth insights into the quantitative results. In this way, underlying, but hidden, aspects of quantitative results are unravelled through the qualitative analysis, hence providing a more robust overall measure (Wisdom \& Creswell, 2013).

The quantitative data were analysed using the Statistical Package for Social Sciences (SPSS) version 24.0. Descriptive statistics were used to analyse demographic profiles of the respondents, while the validity of measurement scale was tested using exploratory factor analysis and principal component analysis (PCA) with varimax rotation. Multiple linear regression (MLR) was used to explore whether there was a relationship between individual purchasing behaviour (dependent variable) and the legal, ethical and philanthropic CSR dimensions (independent variables). Qualitative data were analysed through content analysis using NVivo 11 Program to generate common themes based on frequency responses.

\section{Data collection and analysis}

The questionnaires were administered to more than 1000 third-year, fourth-year and postgraduate South African university students through Qualtrics, an online survey service accessible to members of the university. A total of 184 questionnaires were returned, of which 145 were used for analysis after data were screened and cleaned. Follow-up semi-structured interviews were conducted with 30 South African university students to probe deeper into the quantitative findings and enable the investigator to interpret the quantitative findings in the context of 'tacit' personal interpretations (Tashakkori, Teddlie, \& Sines, 2012).

The questionnaire consisted of three sections. Section A screened the participants using open-ended questions aimed at identifying those who have knowledge of the concept of CSR and the ability to complete the questionnaire in a meaningful manner. Section B gauged participants' behaviour, using Carroll's four-part definition, towards CSR activities of companies and whether they influence their purchasing decisions. Section $C$ gathered demographic information of the respondents. Interviews also screened participants to identify those who have knowledge of CSR and gather information on other factors, apart from CSP, that influence their purchasing decisions.

A purposeful and convenience sampling method was used to select university students to participate in both survey and interviews. On the one hand, it was purposeful in the sense that only students with knowledge of CSR were considered. Question 1 in the questionnaire and interview schedule asked participants what they understood by the term CSR. A response that indicated awareness and understanding of CSR was of critical importance and acted as 
a 'gatekeeper' prerequisite to answering the subsequent questions. Participants who exhibited a lack of awareness of CSR by not answering the question were eliminated from the study because clearly only respondents who were familiar with the CSR of specific firms could make informed evaluations of the organisations concerned. On the other hand, the sample was convenient in that the selection of university students to participate in the study was more accessible.

\section{Scope of the study}

The study surveyed groups of third-year, fourth-year and postgraduate students from a South African research university. These groups were chosen for various reasons: firstly, as students undergoing tertiary education, they have the level of education required to complete questionnaires and respond meaningfully when interviewed. Only students who had knowledge of what CSR is were considered. Secondly, although students do not usually have large disposable incomes, they have experience of making independent purchasing decisions and hence are able to form and articulate personal opinions on the subject. Thirdly, they are burgeoning elite members of society with likely future leadership positions in industry with significant disposable income and consumer influence. Many will become employees of companies or start their own businesses and thus influence the emphasis put on CSR in the future. Lastly, the university is a multi-cultural, multi-racial urban university, with students selected from across the country. Students with such diverse backgrounds represent a wide range of consumers who actively make purchasing decisions.

\section{Validity and reliability of the scale}

The construct validity of the measurement scale used in the survey was tested by exploratory factor analysis using PCA with orthogonal rotation (varimax). For interviews, validity checks were conducted through an independent interpretation of the data by an independent professional researcher specialising in social studies and having knowledge of CSR. Credibility and truth value ('internal validity' in qualitative research) were ensured by using verbatims that objectively captured individual experiences (Bekhet \& Zauszniewski, 2012). The construct reliability of the survey measures was assessed using Cronbach's alpha coefficients. The Cronbach's alpha coefficient of the three independent variables (legal, ethical and philanthropic) and one dependent variable (individual purchasing behaviour) was $\alpha=0.733$. The generally accepted lower limit for Cronbach's alpha is 0.7 , although this may decrease to approximately 0.6 in exploratory research (Hair, Black, Babin, \& Anderson, 2010).

\section{Ethical consideration}

The university ethics clearance committee approved the questionnaire used in the study. Consent was obtained from all participants for both questionnaire and interview data collection processes. Professional and academic integrity was maintained throughout the study by handling information anonymously and confidentially for both primary and secondary data. Participants' dignity and privacy were maintained and they were informed that they could voluntarily withdraw from the study at any time.

\section{Results \\ Descriptive results}

This section presents the demographic details of the samples. Table 1 shows that $38.6 \%$ and $61 \%$ of survey respondents, and $37 \%$ and $63 \%$ of interviewees were men and women, respectively. The age group of 25-31 years (35.9\%) represents the majority of participants, followed by $32-38$ years $(26.2 \%)$, 18-24 years $(25.5 \%)$ and $39-45$ years $(12.4 \%)$. None of the sample respondents was above 46 years of age. In terms of educational level, the majority of the respondents were postgraduate students, comprising $67.6 \%$ of total participants, with fourth-year students representing $27.6 \%$ and thirdyear students representing $4.8 \%$. In the interview sample, undergraduates and postgraduates were evenly distributed, with $53.3 \%$ comprising undergraduates and $46.7 \%$ comprising postgraduates. The majority of survey and interview respondents were black Africans (43\%), followed by white people (30\%), Indians and Asians $(17 \%)$ and mixed race $(8 \%)$. The rest of the proportion $(0.7 \%)$ comprised others who did not wish to stipulate race. Finally, in terms of geographical representation, the majority of the participants came from Gauteng (71\%), followed by the Free State and KwaZuluNatal (7.6\%), Limpopo (6.9\%), Mpumalanga (3.4\%), Northern Cape and Western Cape (1.4\%) and, lastly, Eastern Cape $(0.7 \%)$.

\section{Individual evaluations of economic, legal, ethical and philanthropic corporate social responsibility dimensions}

A PCA (with varimax rotation) was conducted on the four dependent variables (economic, legal, ethical and philanthropic) to assess their factor correlational strength

TABLE 1: Demographic profiles of the quantitative and qualitative samples: Questionnaire.

\begin{tabular}{llcc}
\hline Items & Category & Number & $\%$ \\
\hline Gender & Male & 56 & 38.60 \\
Age (year) & Female & 89 & 61.40 \\
& $18-24$ & 37 & 25.50 \\
& $25-31$ & 52 & 35.90 \\
Education & $32-38$ & 38 & 26.20 \\
& $39-45$ & 18 & 12.40 \\
Race & Undergraduates & 47 & 32.40 \\
& Postgraduates & 98 & 67.60 \\
& African & 63 & 43.40 \\
& Mixed race & 12 & 8.30 \\
Province & Indian and Asian & 25 & 17.20 \\
& White & 44 & 30.30 \\
& Other & 1 & 0.70 \\
& Eastern Cape & 1 & 0.70 \\
& The Free State & 11 & 7.60 \\
& Gauteng & 103 & 71.00 \\
& KwaZulu-Natal & 11 & 7.60 \\
& Limpopo & 10 & 6.90 \\
\hline
\end{tabular}


as components. The Kaiser-Meyer-Olkin (KMO) measure of sampling adequacy (KMO index $=0.689$ ) indicates an adequate level of sampling adequacy. Bartlett's test of sphericity (approximate Chi-square $=143.423$, with 10 degrees of freedom) was statistically significant $(p=0.000)$, indicating that the correlation between items were sufficiently large for factor analysis. Using Kaiser's criterion of eigenvalue greater than 1, only component 1 was retained, with three items loaded on it, that is, 0.884 (ethical), 0.735 (philanthropic) and 0.699 (legal). It has an eigenvalue of 2.271, which represents $45.43 \%$ of the variance. Table 2 presents the factor loadings after rotation. The one component retained was interpreted as 'individual evaluation of CSR aspects'.

Based on the findings in Table 2, individuals perceive the legal, ethical and philanthropic variables as items making up a single valid CSR component interpreted as 'individual evaluation of CSR aspects'; hence, this component is made up of items that are reliable in measuring the perceptions of CSP and individual purchasing behaviour. The economic component of a firm is not perceived as an aspect of CSR. Respondents felt that producing goods and services and selling them at a profit benefit the businesses and not the community. They claimed that most of the businesses in South Africa have not practically invested a significant portion of their profits in social causes that aim at addressing key social challenges in their communities. This is supported by the following verbatim responses of the respondents:

'My understanding of CSR is that corporations apart from profit-making motive should be able to take part in community social responsibilities like donations, scholarships.' (Participant 4, Female, Undergraduate)

'Apart from corporations making profits, they should also be mindful of the societal needs, e.g. charging right prices, providing jobs, offer scholarships or other charity work.' (Participant 16, Male, Postgraduate)

\section{Effects of perceptions of corporate social performance on individual purchasing behaviour}

An MLR analysis was performed to establish whether a relationship exists between individual actual purchasing behaviour (dependent variable) and the three CSR dimensions (independent variables) as shown in Tables 3, 4 and 5. In addition, the MLR helps to determine the percentage of variance in three CSR dimensions, which can significantly explain the individual's purchasing behaviour.

TABLE 2: Factor analysis on individual evaluation of corporate social responsibility components.

\begin{tabular}{lcccc}
\hline Components/item variables & $\begin{array}{c}\text { Factor } \\
\text { loading }\end{array}$ & Eigenvalue & $\begin{array}{c}\text { Variance } \\
\mathbf{\%}\end{array}$ & $\begin{array}{c}\text { Total } \\
\text { variance \% }\end{array}$ \\
\hline $\begin{array}{l}\text { CSR components influencing } \\
\text { purchasing behaviour }\end{array}$ & - & 2.271 & 45.43 & 45.43 \\
$\begin{array}{l}\text { Ethical (do what is right, just and fair, } \\
\text { avoid harm) }\end{array}$ & 0.884 & - & - & - \\
$\begin{array}{l}\text { Philanthropic (contribute resources to } \\
\text { the community, improve quality of life) }\end{array}$ & 0.735 & - & - & - \\
\begin{tabular}{l} 
Legal (obey the law) \\
\hline
\end{tabular} & 0.699 & - & - & - \\
\hline
\end{tabular}

CSR, corporate social responsibility.
Table 3 shows positive multiple $R=0.491$, implying that there is a positive linear relationship between the respondents' perception of companies' CSP and their actual purchasing behaviour. The adjusted $R^{2}$ tells us the percentage of variation explained by the three (legal, ethical and philanthropic) CSR components that actually affect individual purchasing behaviour of South African university students. Because the adjusted- $R^{2}(0.225)$ is less than 1 , it indicates that there is a weak linear relationship between individual actual purchasing behaviour and the three CSR dimensions. The legal, ethical and philanthropic CSR components explain approximately $22.5 \%$ of individual actual purchasing behaviour of South African university students. This suggests that there are other more important factors than CSR, which have a more marked bearing on individual student's actual purchasing behaviour.

An analysis of variance (ANOVA) was used to explain whether a combination of the CSR dimensions indeed explains individual purchasing behaviour of South African university students. The ANOVA test (see Table 4) shows there is a statistically significant relationship between the combined three CSR dimensions and individual actual purchasing behaviour $(p=0.000)$. These results imply that the three CSR dimensions significantly influence individual actual purchasing behaviour.

Table 5 explains the relationship between each of the CSR components and individual purchasing behaviour. It shows coefficient results for each of the three CSR components, with individual actual purchasing behaviour as the dependent variable. Table 5 also shows that only the ethical component of the three dimensions is statistically significant ( $p=0.000)$, implying that the ethical component of the companies' CSR explained individual actual purchasing behaviour.

TABLE 3: Model summary of multiple regression.

\begin{tabular}{lcccc}
\hline Model & $\boldsymbol{R}$ & $\boldsymbol{R}$-square & Adjusted $\boldsymbol{R}^{2}$ & $\begin{array}{c}\text { Standard error of } \\
\text { the estimate }\end{array}$ \\
\hline 1 & 0.491 & 0.242 & 0.225 & 0.823 \\
\hline
\end{tabular}

TABLE 4: Analysis of variance of multiple regression

\begin{tabular}{llccccc}
\hline Model & Variable & $\begin{array}{c}\text { Sum of } \\
\text { squares }\end{array}$ & $\begin{array}{c}\text { Degrees of } \\
\text { freedom }\end{array}$ & $\begin{array}{c}\text { Mean } \\
\text { square }\end{array}$ & $\boldsymbol{F}$ & Sig. \\
\hline 1 & Regression & 30.396 & 3 & 10.132 & 14.965 & 0.000 \\
& Residual & 95.466 & 141 & 0.677 & - & - \\
& Total & 125.862 & 144 & - & - & - \\
\hline
\end{tabular}

Sig, significance; F, F-statistic.

TABLE 5: Coefficients of multiple regression.

\begin{tabular}{|c|c|c|c|c|c|c|}
\hline \multirow[t]{2}{*}{ Model } & \multirow[t]{2}{*}{ Variable } & \multicolumn{2}{|c|}{$\begin{array}{l}\text { Unstandardised } \\
\text { coefficients }\end{array}$} & \multicolumn{3}{|c|}{$\begin{array}{c}\text { Standardised } \\
\text { coefficients }\end{array}$} \\
\hline & & B & Std. Error & Beta & $t$ & Sig. \\
\hline \multirow[t]{4}{*}{1} & (Constant) & 1.117 & 0.368 & & 3.031 & 0.003 \\
\hline & $\begin{array}{l}\text { Importance of legal } \\
\text { component in purchases }\end{array}$ & 0.018 & 0.082 & 0.02 & 0.225 & 0.822 \\
\hline & $\begin{array}{l}\text { Importance of ethical } \\
\text { component in purchases }\end{array}$ & 0.467 & 0.112 & 0.418 & 4.148 & 0.000 \\
\hline & $\begin{array}{l}\text { Importance of philanthropic } \\
\text { component in purchases }\end{array}$ & 0.095 & 0.086 & 0.099 & 1.106 & 0.271 \\
\hline
\end{tabular}

$\mathrm{B}$, beta; Std. error, standard error; $t, t$-statistic; Sig. significance. 


\section{Other-than-corporate social performance aspects that influence individual actual purchasing behaviour}

This section focuses on qualitative findings revealing those 'other-than-CSP' aspects (see Table 6) that influence individual actual purchasing behaviour. The findings of the quantitative study, where individuals' actual purchasing behaviour is explained, suggest that 'other-than-CSP' aspects explain $77.5 \%$ of the variance in individuals' actual purchasing behaviour.

A major factor revealed to contribute to respondents' lack of CSP consideration in their purchasing decisions is the lack of awareness. The study noted that the participants are less aware of the CSPs of companies whose goods and services they purchase. The following two statements illustrate how the availability of CSP information shapes individual perceptions:

'If I knew of a company that practises CSR, I would definitely buy from it because you feel like you are contributing to the society and you are also investing your money somewhere for a good cause that would come back to help those around you.' (Participant 21/Female/Undergraduate)

'Because mostly I do not know which companies do CSR, but in a situation where I know of a company that practises CSR, I would definitely buy from it, and also another thing is that it depends if it is a cause that I am interested in.' (Participant 19/Male/Undergraduate)

Apart from lack of awareness, the coding references for 'other-than-CSP' aspects that affect purchasing behaviour are summarised in Table 6 . Coding references refer to the number of times a theme is mentioned by the respondents. From Table 6, it is clear that price emerged as the most important criterion in respondents' actual purchases of goods and services. Other major influential factors mentioned by the respondents include quality, necessity, customer service and convenience. Also health and safety, brands, crisis management, animal welfare and environment are shown to play a minor role in respondents' purchasing decisions.

\section{Discussion}

The findings of this article highlight the influential role of CSR in individual buying behaviour, especially at grassroots level in South African context. Particularly, its results have shown the empirical applicability of Carroll's CSR pyramid

TABLE 6: Coding references for other-than-corporate social performance aspects that affect purchasing behaviour.

\begin{tabular}{lc}
\hline Themes & Coding references \\
\hline Price & 22 \\
Quality & 20 \\
Necessity & 15 \\
Customer service & 13 \\
Health and safety & 4 \\
Brands & 4 \\
Crisis management & 3 \\
Animal welfare & 3 \\
Environment & 1 \\
\hline
\end{tabular}

(Carroll, 1991) as a framework for defining CSR and its understanding in the context of individual purchasing decisions in South African university students, which is our study context. Unlike Carroll's view that economic responsibility is an essential component of CSR, our findings show that individual consumers in South Africa do not perceive the economic activities of a firm as part of CSR and hence this aspect does not directly affect their purchasing behaviour. This was evident, although it appeared that respondents (as indicated in responses) understood that economic viability is a sine qua non for CSR involvement. This finding concurs with Aupperle, Carroll and Hatfield's (1985, p. 458) findings, in which they found that 'social responsibility can be measured in terms of the importance of the three non-economic components - essentially excluding economic components'.

Furthermore, the results show that there is a positive, statistically linear relationship between the respondents' perceptions of companies' CSP and their actual purchasing behaviour. It shows that those companies that practise CSR are more likely to be favoured by consumers, which translates into the actual purchases of goods and services. These results concur with previous research findings, for instance, Trudel and Cotte (2009), Lin, Chen, Chiu and Lee (2011) and Sen, Bhattacharya and Korschun (2006), which found a positive relationship between CSR activities and customer's buying behaviour. Others studies include those of Brown and Dacin (1997) and Sprinkle and Maines (2010) who found that when a consumer identifies with a company involved in social causes, the overall evaluation of the company is more positive and consumers are more inclined to buy from that company, especially where parity in price and quality exists.

Although individuals stated that a company's CSR has an impact on their actual purchasing decisions, the study reveals that CSR plays a minor role in the totality of their purchasing decision. The qualitative findings identified several other factors that have a greater influence on individual actual purchasing behaviour. Amajor contributing factor is the lack of awareness of the CSP of companies. Previous studies (e.g. Bhattacharya \& Sen, 2004; Öberseder et al., 2011; Pomering \& Dolnicar, 2009) have shown that consumers' awareness of CSR activities is a precondition of its benefits (Fatma et al., 2015). This is despite heterogeneity among consumers with regard to their level of awareness and knowledge about CSR activities (Beckmann, 2007). The findings corroborate previous studies that consumers generally have low levels of awareness of CSR (e.g. Pomering \& Dolnicar, 2009; Sen et al., 2006), and this low level of awareness inhibits consumers' sensitivity to CSR. The low level of awareness also explains why CSR is not a more influential factor when consumers appraise a company and its products (Maignan, 2001; Smith, 2001). Nonetheless, where respondents knew of companies' CSR activities, this promoted their positive attitudes and stronger behavioural intentions about buying products from a socially responsible company, a finding that is in line with previous studies 
(Arli \& Lasmono, 2010; Sen et al., 2006). Moreover, other-thanCSP aspects (see Table 6) seem to play a major role in individual's purchasing behaviour. Our findings affirm other research (e.g. Beckmann, Christensen, \& Christensen, 2007; Belk, Devinney, \& Eckhardt, 2005; Kaur, 2013; Lichtenstein, Drumwright, \& Braig, 2004) that depicts that CSR is not 'at the top of many consumers' lists' when shopping (Bray, Johns, \& Kilburn, 2011). On the contrary, Carrigan and Attalla (2001, p. 570) established that 'price, value, brand image and trend are the most important factors that influence consumer choice', while Öberseder et al. (2011) stated that CSR is a peripheral factor rather than a core factor in consumers' purchase decision-making processes.

It is also evident from the results of the study that ethical CSR components, in particular, seem to contribute significantly to explain the variance in actual CSR-influenced purchasing behaviour. The findings imply that although individual respondents consider the three CSR dimensions in their purchasing decisions, only ethical activities make a significant contribution. Placing ethical responsibility at the top of the CSR pyramid implies that the respondents strongly believe in the need for companies that produce goods and services they purchase from to act in an ethical manner to all stakeholders, especially customers and community - to do no harm to the people they serve and to be just and fair. Our findings concur with those of Creyer (1997) who established that a company's level of ethical behaviour is an important consideration in consumers' purchasing decisions. Our results also affirm Carroll's (2016) assertion that:

\footnotetext{
... though the ethical responsibility is depicted in the pyramid as a separate category of CSR, it should also be seen as a factor which cuts through and saturates the entire pyramid. Ethical considerations are present in each of the other responsibility categories as well. (p. 5)
}

Interestingly, our results appear to dispute Visser's (2005) findings that in Africa ethics appear to have minimal effect on the CSR agenda.

Compared with other countries, our results also indicate that South Africans university students seem to view CSR differently, especially in relation to the way it influences their buying behaviour. For instance, our findings differ from that of Rahim, Jalaludin and Tajuddin (2011) who found that Malaysian consumers consider all the CSR components in their buying decisions, as well as Eshra and Beshir (2017) who found that Egyptian consumers do not think about any of the CSR dimensions in their buying decisions. Our findings further differed from that of Nochai and Nochai (2014) who found that consumers in Bangkok primarily consider the legal and ethical responsibilities in their buying behaviour. The focus by South Africans on ethical aspects of CSR over other factors may partly be attributed to the suspicion many consumers in this country harbour towards businesses in general and big businesses in particular, especially arising from its past often exploitive and repressive role in the economy and society as a whole.

\section{Conclusion}

This article set out to assess the effects of South African university students' perceptions of CSP on the purchasing behaviour. Results of this study aimed to make a theoretical and empirical analysis of the extant knowledge of CSR in the South African context. The study provides new insights into the role of CSR in individual's purchasing behaviour. The findings showed that South African university students' perceptions of companies' CSP positively influenced their actual purchasing behaviour. However, despite these positive perceptions, they do not necessarily translate into actual purchases of goods and services. The results indicated that CSP plays a relatively minor role in South African university students' purchasing behaviour and that other-than-CSP aspects, such as price, quality, necessity, customer service, brand and purchasing convenience, often take precedence.

The findings of the study also demonstrated that the relative importance of Carroll's ranking of CSR constructs varies in South African context. The study highlights different aspects of CSR that are important in consumers' purchasing decisions and questions the applicability of Carroll's rigidly hierarchical CSR model in the South African context. Although the investigation confirms the general applicability of Carroll's (1991) model of CSR to individuals' purchasing decisions in South Africa, it challenges the specific applicability of the order of relative importance of these responsibilities in developing countries, in line with Visser's (2006) study.

On a more specific and contextual level, the findings of this study have debunked the idea that ethical company performance in CSR may be of low concern to African consumers. In the South African context, at least, the study has tentatively shown that ethical behaviour by organisations is important and that it influences purchasing behaviour of consumers.

Managers should note that this research supports the substantive findings reported in the literature, showing that for a considerable number of consumers, a company's level of social responsibility has some importance in their actual purchasing decisions (e.g. Jones, 1997; Ross, Patterson, \& Stutts, 1992). It should also be noted that the selected South African university students did not perceive economic responsibility as a CSR component, which may be regarded as a caution to companies that are profitable but do not contribute to societal well-being. Managers of different business entities should take advantage of this information to help them understand stakeholder expectations and look for ways to create, support and sustain CSR programmes that appeal to this group by going beyond their primary economic responsibility to include social and environmental responsibilities that foster a sense of identification and satisfaction with the company.

This study further suggests that to improve CSR engagement by companies, policymakers should educate the public on what CSR entails and why it is significant, thereby promoting 
a greater understanding of how the community benefits. They should also make information on the social responsibility performance of companies widely available through effective channels such as the Internet and the media. Apart from strengthening structures covered by the King Code and the JSE's Social Responsibility Investment Index, policymakers should also enhance legislation such as the Black Economic Empowerment Act to ensure that it redresses the ills of the past and promotes equal economic participation among all the citizens of the country.

Our findings are limited in the following ways: firstly, the sample chosen for the study represents university students from a South African northern public university and, therefore, cannot be considered as representative of the entire population; replication studies in other sets of population would be of great interest to better understand the effects of CSR on individuals' purchasing behaviours. Secondly, as this study concerns theory testing at a particular time and place where we collected data through a permission-based university ethics committee, the results may not be representative of the entire population. Although representative of South African population in terms of socio-demographic profile, our sample is biased towards university students. This can be in terms of their purchasing power that influences their purchasing decisions.

Future research should extend the study to a more inclusive larger population from other regions to better understand the effects of CSP in other social, cultural and economic contexts, and especially in developing countries with their burgeoning economic growth potentialities. Further research should also investigate the effects of CSR on consumer purchasing behaviour longitudinally and, in so doing, increase the generalisability of the findings and our understanding of its causality.

\section{Acknowledgements Competing interests}

The authors declare that they have no financial or personal relationships that may have inappropriately influenced them in writing this article.

\section{Authors' contribution}

R.K. contributed to the theoretical framework, methodology, data analysis, discussion of the results and conclusion of the article. Prof. D.C. conceptualised the study, supervised and commented on and proofread the manuscript.

\section{References}

Arli, D. I. \& Lasmono, H. K. (2010). Consumers' perception of corporate socia responsibility in a developing country. International Journal of Consumer Studies, 34(1), 46-51. https://doi.org/10.1111/j.1470-6431.2009.00824.x

Aupperle, K. E., Carroll, A. B. \& Hatfield, J. D. (1985). An empirical examination of the relationship between corporate social responsibility and profitability. Academy of Management Journal, 28(2), pp. 446-463.

Azmat, F. (2015). Corporate social responsibility, economic globalization and developing countries. Sustainability Accounting, Management and Policy Journal, 6(2), 166-189.
Baden, D. (2016). A reconstruction of Carroll's pyramid of corporate social responsibility for the 21st century International Journal of Corporate Social Responsibility, 1(1), 8 https://doi.org/10.1186/s40991-016-0008-2

Beckmann, S. C. (2007). Consumers and corporate social responsibility: Matching the unmatchable? Australasian Marketing Journal (AMJ), 15(1), 27-36. https://doi. org/10.1016/S1441-3582(07)70026-5

Beckmann, S. C., Christensen, A. S., \& Christensen, A. G. (2001). 'Myths of nature' and environmentally responsible behaviours: An explanatory study. In: Proceedings of the 30th European Marketing Academy. Conference, Bergen: Norwegian School of Management.

Berens, G., Riel, C. B. V. \& Bruggen, G. H. V. (2005). Corporate associations and consumer product responses: The moderating role of corporate brand dominance. Journal of Marketing, 69(3), 35-48. https://doi.org/10.1509/jmkg.69.3.35.66357

Bekhet, A. K. \& Zauszniewski, J. A. (2012). Methodological triangulation: An approach to understanding data. Nurse Researcher, 20(2), 40-43. https://doi.org/10.7748/ to understanding data. Nurs

Belk, R. W., Devinney, T., \& Eckhardt, G. (2005). Consumer ethics across cultures. Consumption Markets \& Culture, 8(3), 275-289. https://doi.org/10.1080/ 10253860500160411

Bhattacharya, C. B. \& Sen, S. (2004). Doing better at doing good: When, why, and how consumers respond to corporate social initiatives. California Management Review, 47(1), 9-24. https://doi.org/10.2307/41166284

Boonpattarakan, A. (2012). An experimental design to test the main and interaction effects of CSR involvement, brand naming, and pricing on purchase intentions in Thailand. International Journal of Business and Management, 7(16), 62. https:// doi.org/10.5539/ijbm.v7n16p62

Bray, J., Johns, N., \& Kilburn, D. (2011). An exploratory study into the factors impeding ethical consumption. Journal of Business Ethics, 98(4), 597-608. https://doi. org/10.1007/s10551-010-0640-9

Brown, T. J. \& Dacin, P. A. (1997). The company and the product: Corporate associations and consumer product responses. The Journal of Marketing, 61(1), 68-84. https:// and consumer product responses. The Jour
doi.org/10.1177/002224299706100106

Butt, I. (2016). Corporate social responsibility and consumer buying behavior in emerging market: A mixed method study. International Journal of Business and Management, 11(7), 211. https://doi.org/10.5539/ijbm.v11n7p211

Carrigan, M., \& Attalla, A. (2001). The myth of the ethical consumer - Do ethics matter in purchase behaviour? Journal of Consumer Marketing, 18(7), 560-578. https:// doi.org/10.1108/07363760110410263

Carroll, A. B. (1979). A three-dimensional conceptual model of corporate performance. Academy of Management Review, 4(4), 497-505. https://doi.org/10.5465/amr. 1979.4498296

Carroll, A. B. (1991). The pyramid of corporate social responsibility: Toward the moral management of organizational stakeholders. Business Horizons, 34(4), 39-48. https://doi.org/10.1016/0007-6813(91)90005-G

Carroll, A. B. (2000). Ethical challenges for business in the new millennium: Corporate social responsibility and models of management morality. Business Ethics Quarterly, 10(1), 33-42. https://doi.org/10.2307/3857692

Carroll, A. B. (2016). Carroll's pyramid of CSR: Taking another look. International Journal of Corporate Social Responsibility, 1(1), 3. https://doi.org/10.1186/ s40991-016-0004-6

Castaldo, S., Perrini, F., Misani, N. \& Tencati, A. (2009). The missing link between corporate social responsibility and consumer trust: The case of fair trade products. Journal of Business Ethics, 84(1), 1-15. https://doi.org/10.1007/s10551-008-9669-4

Coldwell, D. A. (2007). Is research that is both causally adequate and adequate on the level of meaning possible or necessary in business research? A critical analysis of some methodological alternatives. Electronic Journal of Business Research Methods, 5(1), 1-10.

Coldwell, D., \& Joosub, T. (2014). Business case for corporate social responsibility in emerging economies? An exploratory empirical study of the South African business context. In G. Eweje (Ed.), Corporate social responsibility and sustainability: Emerging trends in developing economies (pp. 297-322). Emerald Group Publishing Limited: Bingley, UK.

Cone Communications/Ebiquity Global. (2015). 2015-cone-communications ebiquity-global-csr-study. Retrieved from http://www.conecomm.com/2015cone-communications-ebiquity-global-csr-study-pdf

Crane, A., McWilliams, A., Matten, D., Moon, J., \& Siegel, D. S. (2008). The Oxford handbook of corporate social responsibility. Oxford, UK: Oxford University Press.

Creyer, E. H. (1997). The influence of firm behavior on purchase intention: Do consumers really care about business ethics? Journal of Consumer Marketing, 14(6), 421-432. https://doi.org/10.1108/07363769710185999

Eshra, N. \& Beshir, N. (2017). Impact of corporate social responsibility on consumer buying behavior in Egypt. World Review of Business Research, 7(1), 32-44.

Fatma, M., Rahman, Z., \& Khan, I. (2015). The role of CSR as a determinant of consumer responses in financial sector. Decision, 42(4), 393-401. https://doi. org/10.1007/s40622-015-0108-y

Flores-Araoz, M. (2011). Corporate social responsibility in South Africa: More than a nice intention. Retrieved from http://www. polity.org.za/article/corporate-socialresponsibility-in-south-africa-more-than-a-nice-intention-2011-09-12

Ghobadian, A., Money, K., \& Hillenbrand, C. (2015). Corporate responsibility research: Past - present - future.

Hair, J. F. Black, W. C., Babin, B. J., \& Anderson, R.E. (2010). Multivariate data analysis, a global perspective (7th edn., p. 816). Upper Saddle River, NJ: Pearson.

HR Pulse. (2016). The importance of corporate social responsibility in Africa. Retrieved from http://www.hrpulse.co.za/editors-pick/234117-the-importance-of-corporatesocial-responsibility-in-africa 
Idemudia, U. (2011). Corporate social responsibility and developing countries moving the critical CSR research agenda in Africa forward. Progress in Development the critical (1), 1-18. https://doi.org/10.1177/146499341001100101

Jamali, D. \& Mirshak, R. (2007). Corporate social responsibility (CSR): Theory and practice in a developing country context. Journal of Business Ethics, 72(3), 243-262. https://doi.org/10.1007/s10551-006-9168-4

Jones, D. (1997). Good works, good business. USA Today, 25, 1B-2B.

Juggernath, S., Rampersad, R., \& Reddy, K. (2011). Corporate responsibility for socioeconomic transformation: A focus on broad-based black economic empowerment and its implementation in South Africa. African Journal of Business Management 5(20), 8224.

Kaur, M. P. (2013). CSR and consumer affairs, an unresolved paradox: An empirical study in Indian perspective. International Journal of Humanities and Social Science Invention, 2(11), 58-66.

Lichtenstein, D. R., Drumwright, M. E., \& Braig, B. M. (2004). The effect of corporate social responsibility on customer donations to corporate-supported nonprofits. Journal of Marketing, 68(4), 16-32. https://doi.org/10.1509/jmkg.68.4.16. 42726

Lin, C.-P., Chen, S.-C., Chiu, C.-K., \& Lee, W.-Y. (2011). Understanding purchase intention during product-harm crises: Moderating effects of perceived corporate ability and corporate social responsibility. Journal of Business Ethics, 102(3), 455. https://doi. corporate social responsibility. Jo
org/10.1007/s10551-011-0824-y

Maignan, I. (2001). Consumers' perceptions of corporate social responsibilities: A cross-cultural comparison. Journal of Business Ethics, 30(1), 57-72. https://doi. org/10.1023/A:1006433928640

Marquina, P. (2010). The influence of corporate social responsibility on Peruvian's consumers purchasing behavior. Journal of Leadership, Accountability and Ethics, $8(2), 70$.

Mohr, L. A., Webb, D. J., \& Harris, K. E. (2001). Do consumers expect companies to be socially responsible? The impact of corporate social responsibility on buying behavior. Journal of Consumer Affairs, 35(1), 45-72. https://doi.org/10.1111/ j.1745-6606.2001.tb00102.x

Newell, P. (2005). Citizenship, accountability and community: The limits of the CSR agenda. International Affairs, 81(3), 541-557. https://doi.org/10.1111/j.14682346.2005.00468.x

Nochai, R., \& Nochai, T. (2014). The effect of dimensions of corporate social responsibility on consumers' buying behavior in Thailand: A case study in Bangkok. Presented at the International Conference on Economics, Social Sciences and Languages, Singapore. Retrieved from http://icehm.org/siteadmin/upload/ 5031ED0514068.pdf

Öberseder, M., Schlegelmilch, B. B., \& Gruber, V. (2011). 'Why don't consumers care about CSR?': A qualitative study exploring the role of CSR in consumption decisions. Journal of Business Ethics, 104(4), 449-460. https://doi.org/10.1007/ s10551-011-0925-7

Peters, A. (2009). Pathways out of the crisis: CSR as a strategic tool for the future. Gütersloh: Bertelsmann Stiftung. Retrieved from http://www.BertelsmannStiftung.de/Cps/Rde/Xbcr/SID-40BBE5BE-11A0895D/Bst_engl/Xcms_bst_dms 30240_30241_2.Pdf

Piedade, L. D., \& Thomas, A. (2006). The case for corporate responsibility: Arguments from the literature. SA Journal of Human Resource Management, 4(2), 57. https:// doi.org/10.4102/sajhrm.v4i2.90

Pino, G., Amatulli, C., De Angelis, M. \& Peluso, A. M. (2016). The influence of corporate social responsibility on consumers' attitudes and intentions toward genetically modified foods: Evidence from Italy. Journal of Cleaner Production, 112, 2861-2869. https://doi.org/10.1016/j.jclepro.2015.10.008

Pomering, A. \& Dolnicar, S. (2009). Assessing the prerequisite of successful CSR implementation: Are consumers aware of CSR initiatives? Journal of Business Ethics, 85(2), 285-301. https://doi.org/10.1007/s10551-008-9729-9

Rahim, R. A., Jalaludin, F. W., \& Tajuddin, K. (2011). The importance of corporate social responsibility on consumer behaviour in Malaysia. Asian Academy of Management Journal, 16(1), 119-139.
Rangan, K., Chase, L. A., \& Karim, S. (2012). Why every company needs a CSR strategy and how to build it. Harvard Business Review. Working paper. Harvard Business School. Retrieved from www.hbs.edu/faculty/Publication\%20Files/12-088.pdf

Romani, S., Grappi, S., \& Bagozzi, R. P. (2016). Corporate socially responsible initiatives and their effects on consumption of green products. Journal of Business Ethics, 135(2), 253-264. https://doi.org/10.1007/s10551-014-2485-0

Ross III, J. K., Patterson, L. T., \& Stutts, M. A. (1992). Consumer perceptions of organizations that use cause-related marketing. Journal of the Academy of Marketing Science, 20(1), 93-97. https://doi.org/10.1007/BF02723480

Scherer, A. G., \& Palazzo, G. 2011. The new political role of business in a globalized world: A review of a new perspective on CSR and its implications for the firm, governance, and democracy. Journal of Management Studies, 48(4), 899-931. https://doi.org/10.1111/j.1467-6486.2010.00950.x

Sen, S., \& Bhattacharya, C. B. (2001). Does doing good always lead to doing better? Consumer reactions to corporate social responsibility. Journal of Marketing Research, 38(2), 225-243. https://doi.org/10.1509/jmkr.38.2.225.18838

Sen, S., Bhattacharya, C. B., \& Korschun, D. (2006). The role of corporate social responsibility in strengthening multiple stakeholder relationships: A field experiment. Journal of the Academy of Marketing Science, 34(2), 158-166. https://doi.org/10.1177/0092070305284978

Skinner, C., \& Mersham, G. (2008). Corporate social responsibility in South Africa: Emerging trends. Society and Business Review, 3(3), 239-255. https://doi.org/ 10.1108/17465680810907314

Smith, N. C. (2001). Changes in corporate practices in response to public interest advocacy and actions. In P.N. Bloom \& G.T. Gundlach (Eds.), Handbook of marketing and society (pp. 140-161). Thousand Oaks, CA: Sage.

Smith, V., \& Langford, P. (2009). Evaluating the impact of corporate social responsibility programs on consumers. Journal of Management \& Organization, 15(1), 97-109.

Sprinkle, G. B., \& Maines, L. A. (2010). The benefits and costs of corporate social responsibility. Business Horizons, 53(5), 445-453. https://doi.org/10.1016/j. bushor.2010.05.006

Suciu, S., Gherheş, V., \& Petcu, D. (2010). Corporate social responsibility - A conceptual approach. Anale. Seria Ştiinţe Economice. Timişoara, XVI, 844-849.

Tashakkori, A., Teddlie, C., \& Sines, M. C. (2012). Utilizing mixed methods in psychological research. In I. B. Weiner, J. A. Schinka \& W. F. Velicer (Eds.), Handbook of Psychology, Vol. 2, pp. 428-450, New York, NY: John Wiley \& Sons.

Trudel, R., \& Cotte, J. (2009). Does it pay to be good?. MIT Sloan Management Review, 50(2), 61.

Van Heerden, N., \& De Beer, E. (2016). Corporate social responsibility communication: A consumer survey at the National Zoological Gardens of South Africa. Communitas, 21(1), 145-164. https://doi.org/10.18820/24150525/Comm.v21.10

Verhoeven, H., Murthy, C. S. R., \& Soares de Oliveira, R. (2014). 'Our identity is our currency': South Africa, the responsibility to protect and the logic of African intervention. Conflict, Security \& Development, 14(4), 509-534. https://doi.org/1 0.1080/14678802.2014.930594

Visser, W. (2005). Corporate citizenship in South Africa: A review of progress since democracy. The Journal of Corporate Citizenship, 18, 29. https://doi.org/10.9774/ GLEAF.4700.2005.su.00007

Visser, W. (2006). Revisiting Carroll's CSR pyramid: An African perspective. In E. R. Pedersen \& M. Huniche (Eds.), Corporate citizenship in developing countries: New partnership perspective (pp. 29-56). Copenhagen: Copenhagen Business Schoo Press.

Wall, D. (2017). CSR demanding increasing share of consumers' minds - and wallets. Retrieved from https://www.nbforum.com/nbreport/csr-demanding-increasingshare-consumers-minds-wallets/

Wisdom, J., \& Creswell, J. (2013). Mixed methods: Integrating quantitative and qualitative data collection and analysis while studying patient-centered medical home models. Rockville, MD: Agency for Healthcare Research and Quality.

Wood, D. J. (1991). Corporate social performance revisited. Academy of Management. The Academy of Management Review, 16(4), 691. 